\title{
Farrukh Iqbal* and Youssouf Kiendrebeogo Public Spending and Education Attainment in the Middle East and North Africa
}

DOI 10.1515/rmeef-2015-0020

Abstract: The Middle East and North Africa (MENA) region has performed the best among all regions in improving education attainment over the past four decades (1970-2010). Using econometric analysis, we show that this was due in large part to a convergence process in which countries that had low levels of education in 1970 increased their stocks much faster than those with higher initial education. Since MENA had the second lowest education stock among all regions in 1970, it benefited substantially from convergence over the next four decades. We also show that MENA obtained a comparative edge from having had the highest rate of public spending on education among all developing country regions. Such spending, however, was of middling efficiency and did little to produce education of good quality.

Keywords: education growth, public spending on education, Middle East and North Africa

\section{Introduction}

It is generally acknowledged that education attainment has advanced significantly in the countries of the Middle East and North Africa region (hereafter referred to as MENA) over the years (Rugh 2002; Iqbal 2006). This progress is documented in the first two columns of Table 1 which shows how the stock of education, as measured by the average years of schooling completed per person over the age of 15, has evolved for fifteen MENA countries over the period 1970-2010. ${ }^{1}$ Each and every country in the table shows a significant increase in education stock. One could show similar progress as well using other measures of education attainment such as improvements in primary and secondary school enrolment rates.

1 Internationally comparative data on years of schooling completed are reported by Barro and Lee (2013). The Barro-Lee dataset does not include information for Oman and Lebanon.

*Corresponding author: Farrukh Iqbal, World Bank, 1818 H Street NW, Washington DC 20433, USA, E-mail: fiqbalus@gmail.com Youssouf Kiendrebeogo, World Bank, 1818 H Street NW, Washington DC 20433, USA, E-mail: ykiendrebeogo@worldbank.org 
Table 1: Increase in education stocks among MENA countries (1970-2010).

\begin{tabular}{lrrrrr}
\hline Country & $\begin{array}{r}\boldsymbol{A} \\
\text { Years of } \\
\text { schooling } \\
(\mathbf{1 9 7 0 )}\end{array}$ & $\begin{array}{r}\boldsymbol{B} \\
\text { Years of } \\
\text { schooling } \\
\mathbf{( 2 0 1 0 )}\end{array}$ & $\begin{array}{r}\boldsymbol{C}=\boldsymbol{B}-\boldsymbol{A} \\
\text { Increase in } \\
\text { years of } \\
\text { schooling }\end{array}$ & $\begin{array}{r}\boldsymbol{D}=\boldsymbol{C} / \boldsymbol{A} \\
\text { Percentage } \\
\text { increase (\%) }\end{array}$ & $\begin{array}{r}\boldsymbol{E} \\
\text { Global rank } \\
(\boldsymbol{N}=\mathbf{1 4 5})\end{array}$ \\
\hline Yemen & 0.06 & 3.7 & 3.6 & $6,053.5$ & 1 \\
Libya & 1.5 & 8.2 & 6.7 & 444.9 & 6 \\
Egypt & 1.3 & 6.9 & 5.6 & 433.9 & 8 \\
Morocco & 0.9 & 5.0 & 4.1 & 408.5 & 10 \\
Algeria & 1.5 & 7.6 & 6.1 & 405.1 & 11 \\
Iraq & 1.3 & 5.9 & 4.6 & 335.1 & 17 \\
Iran & 2.0 & 8.6 & 6.6 & 331.3 & 19 \\
Tunisia & 1.7 & 7.2 & 5.5 & 314.6 & 21 \\
United Arab Emirates & 2.5 & 9.1 & 6.6 & 261.2 & 26 \\
Bahrain & 3.0 & 9.6 & 6.6 & 213.2 & 33 \\
Jordan & 3.4 & 9.1 & 5.7 & 167.2 & 45 \\
Saudi Arabia & 3.2 & 8.4 & 5.2 & 158.3 & 47 \\
Syria & 2.2 & 5.2 & 3.0 & 135.6 & 57 \\
Qatar & 3.8 & 7.4 & 3.6 & 95.0 & 75 \\
Kuwait & 3.2 & 6.3 & 3.1 & 94.0 & 78 \\
\hline
\end{tabular}

Source: Barro and Lee (2013).

What is less appreciated is that MENA has achieved the best performance in education attainment in the world over the last four decades. A hint of this is provided in the fifth column of Table 1 which shows that all but two MENA countries (Qatar and Kuwait) feature in the top half of the global league when ranked by percentage change in education stock between 1970 and 2010 .

A clearer sense of the relative performance of MENA can be obtained from looking at trends in regionally aggregated data. Table 2 provides population

Table 2: Average years of schooling completed, by region and over time.

\begin{tabular}{lrrrrrr}
\hline & 1970 & 1980 & 1990 & 2000 & 2010 & $\begin{array}{r}\text { Increase (\%) } \\
\text { 1970-2010 }\end{array}$ \\
\hline Middle East/North Africa & 2.1 & 3.3 & 4.8 & 6.1 & 7.2 & 239.0 \\
East Asia/Pacific & 3.9 & 5.0 & 5.9 & 6.7 & 7.6 & 95.7 \\
Europe/Central Asia & 6.0 & 7.4 & 8.5 & 9.5 & 10.0 & 66.5 \\
Latin America/Caribbean & 4.4 & 5.5 & 6.5 & 7.4 & 8.4 & 89.2 \\
South Asia & 2.4 & 3.0 & 3.8 & 4.7 & 5.9 & 145.6 \\
Sub-Saharan Africa & 1.9 & 2.7 & 3.7 & 4.5 & 5.4 & 180.4 \\
OECD & 7.5 & 8.6 & 9.3 & 10.2 & 10.9 & 44.8 \\
\hline
\end{tabular}

Source: Compiled from Barro and Lee (2013). 
weighted averages for education stock for each of the developing country regions (see Annex 1 for list of countries included in each region) and the high-income OECD group of countries for the period 1970-2010. The table shows that the greatest percentage increase in education stock (239\%) during the past 40 years occurred in MENA.

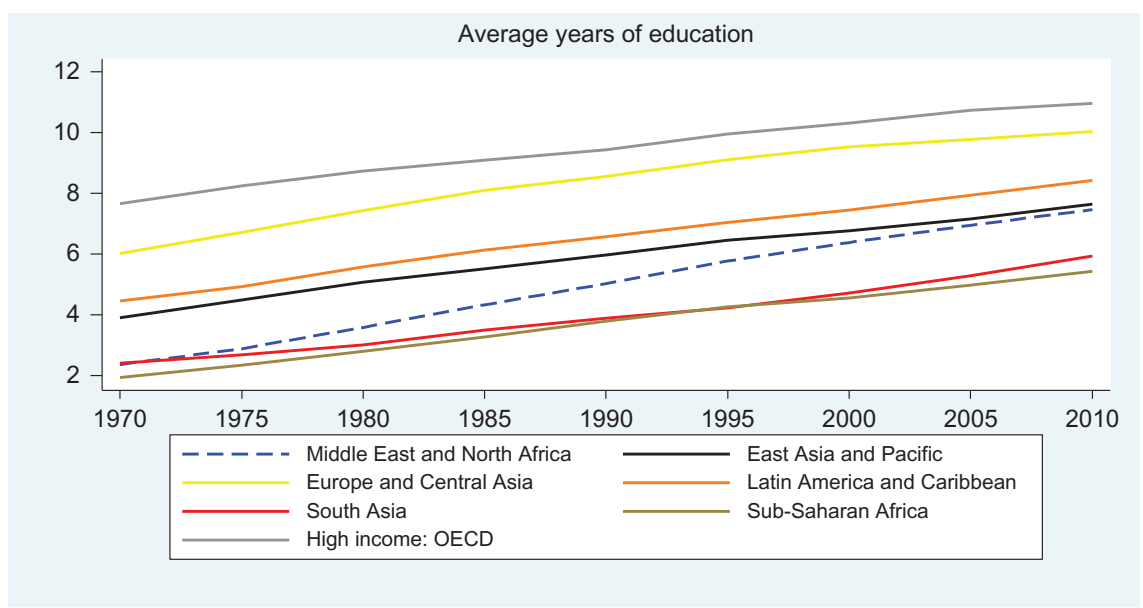

Figure 1: Evolution of education stocks across regions, 1970-2010.

Note: MENA region in dashed line.

Source: Compiled from Barro and Lee (2013).

Figure 1 graphs regional data for education stocks at 5-year intervals between 1970 and 2010. It shows that the MENA region was clustered at the low-stock end with South Asia and Sub-Saharan Africa in 1970 but diverged from this cluster over the next 40 years. By 2010, it had converged with the East Asia region and narrowed the gap with the Latin America and Caribbean region. In doing so, it experienced the fastest rate of stock growth among all regions over the past four decades. $^{2}$

Our purpose in this paper is to determine what has accounted for the better comparative performance of MENA. We first check what the literature has to say about the determinants of educational attainment in Section 2. Then we develop an econometric model in Section 3 to investigate this question more rigorously. In Section 4, we report empirical results and a few robustness checks. These show that public spending on education was the policy lever with the strongest

2 Similar performance by the MENA region is also found for other time intervals. See Glewwe and Kremer (2006) for comparative performance over 1960-2000. 
effect on education outcomes. In Section 5, we provide some additional observations on the comparative efficiency of public spending in MENA and on its link with education quality.

\section{Determinants of Education Attainment: A Brief Literature Survey}

An overview of the literature shows that public spending on education (on schools, teachers, administrators, and ancillary facilities and equipment) is considered the key determinant of education attainment in developing countries. In addition, a variety of socioeconomic variables are typically included as independent determinants. Some of these are thought to have a bearing on the effectiveness with which public spending is transformed into successful education performance. Others are thought to have a direct influence on education attainment. Below, we discuss public spending and the following additional variables that often feature in the literature: income; child health; child employment; and urbanization.

\subsection{Public Spending}

The notion that education attainment is primarily a function of public spending is at the heart of most cross-country empirical work done to date. Representative citations include Gupta et al. (2002) and Baldacci et al. (2003) for developing countries. Public spending is expected to be of special relevance to MENA because most countries there had adopted a model of publicly financed and delivered provision of education by the 1960s and have continued to implement this model into current times (Rugh 2002). Lebanon is possibly the only MENA country where the private sector has historically had a more prominent role than the public sector in the delivery of education services.

\subsection{Income}

Just as public spending is thought to capture the supply side of education, income is thought to capture the demand side. The assumption is that the demand for education rises with family income. Income can also stand in for other household-level factors such as the occupation and education of parents. These factors are widely considered to be important determinants of education 
demand (Hanushek 1995). Using current income per capita as an independent variable raises concerns about endogeneity since higher incomes could be an outcome of better education levels as much as an input toward them. These concerns are dealt with through appropriate econometric methods (see Baldacci et al. 2008; Goldin and Katz 1997).

\subsection{Child Health}

The effective demand for education may also be affected by such factors as child health. Children who are less healthy for any reason are likely to be absent for more days from school, to repeat grades and to drop out at higher rates and earlier ages. Several studies have used child mortality rates as a proxy for child health (see, for example, Gupta et al. 2002; Baldacci et al. 2008). Another relevant proxy could be the adequacy of food or caloric intake which is likely to be directly influenced by government policies focused on food security. This may be of particular interest for MENA because food subsidies have long been a distinctive characteristic of the region (Iqbal 2006).

\subsection{Child Employment}

Whether a family decides to allow a child to get additional years of schooling depends in part on the opportunity costs of education at each successive year. In general, these costs increase with the scope for employment among children of school-going age. For example, where there are many opportunities for children to be employed and it is culturally acceptable for children to work, one would expect this to decrease the desire among families to send their children to school. Thus, countries where a larger fraction of children are employed are also likely to be countries with a slower rate of improvement in education attainment. Goldin and Katz (1997) include the availability and wages of manufacturing sector jobs among the factors they use to that explain differences in the rate of secondary school graduation among US states over the period 19101940. Getting a job competed with the desire to spend more years in high school at this early stage in the evolution of education in the United States.

\subsection{Urbanization}

Greater urbanization typically reflects higher population densities which means that schools in such locations can reap economies of scale. Urbanized settings 
also facilitate easier access to schools through better transport, for example, and thus reduce the opportunity cost of accessing education. Accordingly, urbanization features as an independent variable in several studies in the literature (see, for example, Gupta et al. 2002; Baldacci et al. 2008). Urbanization could be especially relevant for MENA because many countries in MENA are resource rich and the tendency toward urbanization is enhanced in resource-rich countries. ${ }^{3}$ This is because resource booms make traditional tradable goods sectors (typically agriculture for many developing countries) less competitive over time due to exchange rate appreciation and induce labor reallocations toward nontradable sectors (commonly referred to as Dutch Disease effects; see Corden 1984). Since the latter usually comprise urban-based services such as construction, education, and retail trade, the rate of urbanization tends to be faster, ceteris paribus, in such countries than in resource-poor countries.

\section{Empirical Model and Data}

The empirical model that is typically found in the literature is of the following general form:

$$
E_{i}=f\left(\mathrm{PBSE}_{i}, Z_{i}\right)
$$

where the subscript $i$ denotes country, $E$ refers to the measure of education adopted as the dependent variable, PBSE refers to public spending on education, and $Z$ refers to a vector of other socioeconomic control variables.

An empirical model to explain changes in education attainment over time may be written in the following general form:

$$
E_{i(t+n)}-E_{i t}=f\left(E_{i t}, \mathrm{PBSE}_{\text {iavg }}, Z_{\text {iavg }}\right)
$$

where the left-hand side refers to the change in $E$ over $n$ year interval from year $t$ to year $t+n$ and, on the right-hand side, $E_{t}$ refers to the initial value of $E$ at time $t$; and the subscript avg refers to the average value of the independent variables over the $n$ year interval.

This empirical model is similar to that found in the available literature in that it considers education attainment as being determined primarily by public expenditures on schools, teachers, and related inputs as well as on factors that have a bearing on the effectiveness of such spending and on the opportunity costs of education. Where it differs is in (a) the definition of the dependent

3 Ten of the 15 countries in Table 1 were among the top 25 oil and gas producers in the world on a per capita basis throughout the last four decades. 
variable as the change in education stocks over time rather than the level at a point in time; (b) the use of the initial stock of education as an independent variable; and (c) the use of average values over 20- to 40-year intervals for most independent variables rather than contemporary values. These three aspects are discussed further below.

\subsection{Dependent Variable}

Most previous studies use the level of education attainment at a given point in time as the dependent variable. For example, Gupta et al. (2002) use gross enrolments in primary and secondary education as their dependent variables. The same is done in Baldacci et al. (2008) although they average enrolment rates over 5 years to get their desired measure of the dependent variable. Since our main interest is in explaining the comparative education performance of MENA over time, we need to focus on changes in education stocks rather than levels. Our dependent variable is, therefore, defined as the change in education stocks between 2010 and 1970 for each country in our sample. A similar change formulation is also used in Goldin and Katz (1997) (together with a level formulation) in their study of differences in high school graduation rates across US states in the first half of the twentieth century.

\subsection{Initial Stock of Education}

In effect, when we define the dependent variable in terms of changes over time, we are doing the equivalent of a "growth" regression rather than an "incomelevel" regression as has become standard in the economic growth literature following the work of Barro (1991). Growth regressions typically use as an independent variable the initial level of income for the year from which growth is being measured. This is consistent with the theoretical basis of the Solow (1956) model which underlies such regressions and is empirically significant as well. By now, the concept of conditional convergence whereby countries with low initial per capita incomes tend to grow faster than those with higher initial incomes has become well established empirically.

Conditional convergence has an intuitive appeal for education performance as well. One would expect that, all other things being equal, a country that has a high level of education to begin with will find it difficult to increase this rate further while countries with lower rates will find it easier to do so. Indeed, for some measures of education, such as net primary or secondary enrollment rates, there are definitional 
ceilings of $100 \%$ that can impose convergence for purely arithmetic reasons. ${ }^{4}$ For the measure we have adopted here, namely, years of education completed by persons over 15, there is no ceiling imposed by the definition of the metric but the fact remains that, once a large fraction of a population has received, say, secondary education, it is harder to get further increases in the average level of education. One begins to run into the more difficult cases at this stage where children do not enroll for reasons related to remote location, disability, age (child needs to work to contribute to family income), or cultural preference (where parents may not wish to enroll female children, for example). On the other hand, it could also be argued that countries with low levels of education to begin with may be in a "poverty trap" from which they may find it hard to break out. Which pattern prevails will have to be left to empirical resolution. ${ }^{5}$

\subsection{Using Past Average Values for Independent Variables}

Each of the independent variables used in the empirical work reported below is measured as an average of past values. This is advantageous in several respects. For example, changes in education over time are more likely to be a function of past levels of spending than of the current level of spending. It takes many years for spending to have an impact on education performance as schools need to be built and teachers need to be trained. Some studies (see Baldacci et al. 2008) have attempted to incorporate this aspect by using 5-year averages for their measure of public spending. Taking averages over past values also serves to mitigate concerns about measurement errors and endogeneity. While measurement errors could be large with respect to data for any given year, averaging over a large number of years reduces the scope for such errors.

The specific empirical equation we estimate is:

$$
\begin{aligned}
\ln E_{i 2010}-\ln E_{i 1970}= & \alpha+\beta_{0} \ln E_{i 1970}+\beta_{1} \ln \text { Public spending }_{\text {iavg }}+\beta_{2} \text { Growth }_{\text {iavg }} \\
& +\beta_{3} \text { Urban }_{\text {iavg }}+\beta_{3} \text { Undernourishment }_{\text {iavg }} \\
& +\beta_{4} \text { Child Employment }_{i a v g}+\varepsilon_{i}
\end{aligned}
$$

\footnotetext{
4 Sometimes gross enrolment rates of above $100 \%$ are encountered. This means that the numerator (number enrolled) exceeds the denominator (number of children in the relevant age group). This can happen when children above the relevant age group remain among the enrollees because they are repeating grades or are returning to school after an absence.

5 The relationship could also be modeled as an S-shaped curve capturing the idea of slow rates of change at very low and very high levels of education and faster rates of change in between (see Clemens et al. 2007 for a discussion).
} 
$\ln E_{1970}$ and $\ln E_{2010}$ are $\log$ values of education stock of country $i$ in 1970 and 2010, respectively. In Public Spending avg $_{\text {is }}$ the log of the value of per capita public spending on education (averaged over 1980-2010); Growth ${ }_{\text {avg }}$ is the annual growth rate of real GDP per capita (averaged over 1970-2010). Urban $_{\mathrm{avg}}$ refers to the ratio of urban to total population (averaged over 1970-2010). Undernourishment ${ }_{\mathrm{avg}}$ is a proxy for child health and refers to the proportion of the population whose food intake is insufficient to maintain minimum dietary energy needs continuously (averaged over 1990-2010). Child Employment $_{\text {avg }}$ refers to the percentage of children in employment among children aged 7-14 (averaged over 1970-2010). $\varepsilon_{i t}$ is an error term.

Further information on the definitions and sources for the data are provided in Annex 2. Summary statistics are presented in Table 3.

Table 3: Summary statistics.

\begin{tabular}{lccccr}
\hline Variable & Obs. & Mean & S.D. & Min & Max \\
\hline$\Delta$ In education stock & 72 & 0.95 & 0.56 & 0.26 & 4.12 \\
In Initial education stock & 72 & 0.99 & 0.81 & -2.80 & 2.10 \\
In Public spending & 72 & 4.61 & 1.07 & 1.79 & 6.49 \\
Growth & 72 & 2.03 & 1.55 & -0.85 & 8.02 \\
Urban & 72 & 43.73 & 20.01 & 6.30 & 88.25 \\
Undernourishment & 72 & 18.57 & 13.56 & 5 & 63.32 \\
Child employment & 72 & 17.84 & 12.66 & 1 & 67.00 \\
\hline
\end{tabular}

\section{Regression Results and Robustness Checks}

The empirical model specified in eq. [3] is estimated using ordinary least squares (OLS) over a cross-sectional sample of between 72 and 76 developing countries. The regression results are reported in Table 4 in five columns. The first column contains our two main variables of interest, the initial stock of education in 1970, and the average level of public spending on education. The next four columns add one further independent variable at a time to capture the effects of different socioeconomic factors highlighted in the literature.

The results are very clear. All the action is in the first column. The initial stock and public spending explain $88 \%$ of the variation in the change of education stocks across developing countries over the past 40 years. Including other variables in subsequent columns adds only $1 \%$ in explanatory value.

The initial level of education in 1970 has by far the strongest effect on the subsequent attainment of more education over the next four decades. The 
Table 4: Determinants of changes in education stock (OLS regressions; developing countries sample).

\begin{tabular}{|c|c|c|c|c|c|}
\hline Variable & (1) & (2) & (3) & (4) & (5) \\
\hline $\begin{array}{l}\text { In Initial education } \\
\text { stock }\end{array}$ & $\begin{array}{l}-0.685^{\star \star \star} \\
(0.059)\end{array}$ & $\begin{array}{l}-0.685^{\star \star \star} \\
(0.059)\end{array}$ & $-0.727^{\star \star \star}$ & $\begin{array}{l}-0.726^{* \star \star} \\
(0.059)\end{array}$ & $\begin{array}{l}-0.732^{\star \star \star} \\
(0.061)\end{array}$ \\
\hline In Public spending & $\begin{array}{l}0.097^{\star \star \star} \\
(0.025)\end{array}$ & $\begin{array}{l}0.097^{\star \star \star} \\
(0.025)\end{array}$ & $\begin{array}{l}0.065^{\star \star} \\
(0.026)\end{array}$ & $\begin{array}{l}0.071^{\star \star} \\
(0.027)\end{array}$ & $\begin{array}{l}0.064^{\star \star} \\
(0.026)\end{array}$ \\
\hline Growth & & $\begin{array}{r}3.88 \mathrm{e}-03 \\
(0.012)\end{array}$ & $\begin{array}{r}-2.83 e-03 \\
(0.015)\end{array}$ & $\begin{array}{r}-6.84 \mathrm{e}-04 \\
(0.015)\end{array}$ & $\begin{array}{r}4.36 \mathrm{e}-03 \\
(0.015)\end{array}$ \\
\hline Undernourishment & & & $\begin{array}{l}-6.86 \mathrm{e}-03^{\star \star} \\
(2.94 \mathrm{e}-03)\end{array}$ & $\begin{array}{l}-7.50 \mathrm{e}-03^{* *} \\
(3.28 \mathrm{e}-03)\end{array}$ & $\begin{array}{l}-6.83 \mathrm{e}-03^{\star \star} \\
(3.40 \mathrm{e}-03)\end{array}$ \\
\hline Child employment & & & & $\begin{array}{r}1.89 \mathrm{e}-03 \\
(2.79 \mathrm{e}-03)\end{array}$ & $\begin{array}{r}2.12 \mathrm{e}-03 \\
(2.82 \mathrm{e}-03)\end{array}$ \\
\hline Urban & & & & & $\begin{array}{r}1.21 \mathrm{e}-03 \\
(1.28 \mathrm{e}-03)\end{array}$ \\
\hline Constant & $\begin{array}{l}1.175^{\star \star \star} \\
(0.088)\end{array}$ & $\begin{array}{l}1.169^{\star \star \star} \\
(0.090)\end{array}$ & $\begin{array}{l}1.507^{\star \star \star} \\
(0.155)\end{array}$ & $\begin{array}{l}1.4511^{\star \star \star} \\
(0.171)\end{array}$ & $\begin{array}{l}1.406^{\star \star \star} \\
(0.179)\end{array}$ \\
\hline Observations & 76 & 76 & 72 & 72 & 72 \\
\hline Adjusted $R^{2}$ & 0.881 & 0.879 & 0.894 & 0.893 & 0.892 \\
\hline
\end{tabular}

Notes: The dependent variable is the natural logarithm of the change in education stock (19702010). Standardized coefficients are reported with heteroskedasticity - robust standard errors in parentheses. Asterisks denote significance levels as follows: ${ }^{\star \star \star} p<0.01,{ }^{\star \star} p<0.05$, ${ }^{*} p<0.1$. Initial values are for 1970 .

standardized coefficient for this variable is consistent in sign, size, and value across all five columns. The coefficient value of -0.73 implies that countries with an education stock that was 1 standard deviation less than the sample average in 1970 increased their stocks by $73 \%$ more than the average by 2010 . The negative sign on the initial level of education shows that convergence or catch-up has occurred: countries with low initial education stocks have increased their stocks faster than those with higher initial stocks. Thus convergence not only plays a role in income growth (as shown in Barro (1991) and subsequent studies) but also in the growth of education stocks.

The results also show that public spending on education is a significant and positive determinant of education attainment. The higher the public spending on education per capita, the higher the change in education attainment. This is consistent with results reported for public spending on education by Gupta et al. (2002) and Baldacci et al. (2008) among others.

Caloric intake (which we take to reflect child health status) also matters: the worse the undernourishment of the population, the smaller the improvement in 
education attainment. Similarly significant results have been reported using alternative measures of child health such as the child mortality rate (see Gupta et al. 2002; Baldacci et al. 2008).

The income growth variable is not significant in our regressions. While we cannot compare this result directly with other studies in the literature since they use an income-level variable rather than the growth variable, even the level variable produces mixed results. For example, Gupta et al. (2002) report a significant positive association between gross secondary enrollment rates and per capita income but not for gross primary and secondary rates taken together. Baldacci et al. (2008) find current per capita income to be a significant and positive determinant of primary and secondary gross enrollment rates in some but not in all of the models they run.

With regard to urbanization, Gupta et al. (2002) report a significant result for this variable but Baldacci et al. (2008) and Rajkumar and Swaroop (2008) do not. Finally, the opportunity cost of schooling as measured by the child employment rate is not a significant variable in our regression, in contrast to the results reported by Goldin and Katz (1997) for the case of the United States.

We subjected our results to four robustness checks: using alternate proxies for the public spending and income variables; adding other independent variables; adding high-income countries to the sample; and using a two-stage least squares (TSLS) estimator. Our results are robust to each of these checks in the sense that the signs and significance of initial stock and public spending do not change. Table 5 shows the results for the first three robustness checks and Table 6 reports the results for the TSLS run.

The first two columns of Table 6 shows the results of substituting education spending as a share of GDP for education spending per capita and income per capita in place of income growth. Most of the studies cited earlier use these proxies for public spending and income. But the results do not change. Public spending on education is still significant when entered as a ratio to GDP and income is still insignificant when entered as the average level rather than the average growth over time. ${ }^{6}$

The third and fourth columns show the results of adding two new independent variables, control of corruption and ethnic tensions. Such variables have been used in some earlier studies (see, for example, Gupta et al. 2002; Rajkumar and Swaroop 2008) to investigate the effects of institutional quality and political

\footnotetext{
6 The lack of significance of income per capita does not mean that a country's resources are unimportant to the task of accumulating human capital. Resources do have an effect and, in our model, this is being captured by the level of public spending per capita which is directly related to resources.
} 
Table 5: Robustness checks via alternative specifications and sample.

\begin{tabular}{|c|c|c|c|c|c|}
\hline \multicolumn{3}{|l|}{ Variable } & \multicolumn{2}{|c|}{ Developing country sample } & \multirow{2}{*}{$\begin{array}{r}\begin{array}{r}\text { Larger } \\
\text { sample }\end{array} \\
-0.734^{\star \star \star} \\
(0.054)\end{array}$} \\
\hline $\begin{array}{l}\text { In initial } \\
\text { education stock }\end{array}$ & $\begin{array}{l}-0.700^{\star \star \star} \\
(0.057)\end{array}$ & $\begin{array}{l}-0.736^{\star \star \star} \\
(0.063)\end{array}$ & $\begin{array}{l}-0.725^{\star \star \star} \\
(0.064)\end{array}$ & $\begin{array}{l}-0.720^{\star \star \star} \\
(0.076)\end{array}$ & \\
\hline $\begin{array}{l}\text { In Public } \\
\text { spending [1] }\end{array}$ & & $\begin{array}{c}0.053^{\star} \\
(0.030)\end{array}$ & $\begin{array}{l}0.101^{\star \star *} \\
(0.037)\end{array}$ & $\begin{array}{l}0.116^{\star \star \star} \\
(0.036)\end{array}$ & $\begin{array}{c}0.032^{\star} \\
(0.018)\end{array}$ \\
\hline $\begin{array}{l}\text { Public spending } \\
\text { (\% of GDP) }\end{array}$ & $\begin{array}{l}0.025^{\star \star} \\
(0.012)\end{array}$ & & & & \\
\hline Growth & $\begin{array}{r}0.012 \\
(0.015)\end{array}$ & & $\begin{array}{r}6.20 \mathrm{e}-03 \\
(0.014)\end{array}$ & $\begin{array}{c}0.020^{\star} \\
(0.011)\end{array}$ & $\begin{array}{r}8.66 \mathrm{e}-03 \\
(0.013)\end{array}$ \\
\hline In GDP per capita & & $\begin{array}{r}0.029 \\
(0.064)\end{array}$ & & & \\
\hline Undernourishment & $\begin{array}{l}-3.27 \mathrm{e}-03 \\
(2.69 \mathrm{e}-03)\end{array}$ & $\begin{array}{l}-6.56 \mathrm{e}-03^{\star *} \\
(2.95 \mathrm{e}-03)\end{array}$ & $\begin{array}{l}-7.36 \mathrm{e}-03^{* *} \\
(3.57 \mathrm{e}-03)\end{array}$ & $\begin{array}{l}-8.49 \mathrm{e}-03^{*} \\
(5.00 \mathrm{e}-03)\end{array}$ & $\begin{array}{l}-7.35 \mathrm{e}-03^{\star \star} \\
(3.39 \mathrm{e}-03)\end{array}$ \\
\hline Child employment & $\begin{array}{l}-1.13 \mathrm{e}-03 \\
(1.46 \mathrm{e}-03)\end{array}$ & $\begin{array}{r}1.99 \mathrm{e}-03 \\
(2.73 \mathrm{e}-03)\end{array}$ & $\begin{array}{r}1.90 \mathrm{e}-03 \\
(2.69 \mathrm{e}-03)\end{array}$ & $\begin{array}{r}4.25 \mathrm{e}-03 \\
(3.98 \mathrm{e}-03)\end{array}$ & $\begin{array}{r}1.49 \mathrm{e}-03 \\
(2.47 \mathrm{e}-03)\end{array}$ \\
\hline Urban & $\begin{array}{l}4.16 \mathrm{e}-03^{\star \star \star *} \\
(2.09 \mathrm{e}-03)\end{array}$ & $\begin{array}{r}4.89 \mathrm{e}-04 \\
(2.12 \mathrm{e}-03)\end{array}$ & $\begin{array}{r}1.19 \mathrm{e}-03 \\
(1.31 \mathrm{e}-03)\end{array}$ & $\begin{array}{r}1.35 \mathrm{e}-03 \\
(1.59 \mathrm{e}-03)\end{array}$ & $\begin{array}{r}9.97 \mathrm{e}-04 \\
(8.16 \mathrm{e}-04)\end{array}$ \\
\hline $\begin{array}{l}\text { Control of } \\
\text { corruption [2] }\end{array}$ & & & $\begin{array}{l}-0.315 \\
(0.258)\end{array}$ & $\begin{array}{l}-0.309 \\
(0.307)\end{array}$ & \\
\hline $\begin{array}{c}\text { Interaction } \\
{[1] \times[2]}\end{array}$ & & & $\begin{array}{r}0.052 \\
(0.047)\end{array}$ & $\begin{array}{r}0.050 \\
(0.053)\end{array}$ & \\
\hline Ethnic tensions & & & & $\begin{array}{l}-0.027 \\
(0.027)\end{array}$ & \\
\hline Constant & $\begin{array}{l}1.411^{\star \star \star} \\
(0.144)\end{array}$ & $\begin{array}{l}1.287^{\star \star \star} \\
(0.331)\end{array}$ & $\begin{array}{l}1.196^{\star \star \star} \\
(0.233)\end{array}$ & $\begin{array}{l}1.180^{\star \star \star} \\
(0.245)\end{array}$ & $\begin{array}{l}1.570^{\star \star \star} \\
(0.128)\end{array}$ \\
\hline Observations & 91 & 71 & 72 & 61 & 105 \\
\hline Adjusted $R^{2}$ & 0.878 & 0.893 & 0.892 & 0.887 & 0.909 \\
\hline
\end{tabular}

Notes: The dependent variable is the natural logarithm of the change in education stock (19702010). Standardized coefficients are reported with heteroskedasticity - robust standard errors in parentheses. Asterisks denote significance levels as follows: ${ }^{\star \star *} p<0.01,{ }^{\star \star} p<0.05,{ }^{\star} p<0.1$.

context on human capital attainment. In keeping with earlier studies, we have interacted corruption with public spending. These variables are not significant in our regressions and do not change the significance of initial stock or public spending, our two main variables of interest.

The fifth column shows the results of running our basic model over a larger sample of countries, including high-income countries. Once again, no notable change occurs in the results.

Table 6 shows the results of running the model using a TSLS procedure to account for omitted variable bias. We use the initial value (in 1970) of public 
Table 6: Robustness check via TSLS procedure for omitted variables.

\begin{tabular}{lcc}
\hline Variable & First stage1 & Second stage \\
\hline In initial education stock & 0.080 & $-0.731^{\star \star \star}$ \\
Growth & $(0.095)$ & $(0.061)$ \\
& $0.160^{\star \star \star}$ & $5.18 \mathrm{e}-03$ \\
In Public spending & $(0.044)$ & $(0.016)$ \\
& & $0.055^{\star}$ \\
Undernourishment & $-8.94 \mathrm{e}-03$ & $(0.029)$ \\
& $(8.15 \mathrm{e}-03)$ & $-6.95 \mathrm{e}-03^{\star \star}$ \\
Child employment & $1.40 \mathrm{e}-03$ & $(3.42 \mathrm{e}-03)$ \\
& $(5.29 \mathrm{e}-03)$ & $1.95 \mathrm{e}-03$ \\
Urban & $3.86 \mathrm{e}-04$ & $(2.89 \mathrm{e}-03)$ \\
& $(5.59 \mathrm{e}-03)$ & $1.40 \mathrm{e}-03$ \\
In Initial public spending & $0.713^{\star \star \star}$ & $(1.37 \mathrm{e}-03)$ \\
& $(0.083)$ & \\
Constant & $1.372^{\star \star \star}$ & $1.445^{\star \star \star}$ \\
& $(0.422)$ & $(0.196)$ \\
Observations & 72 & 72 \\
Shea's partial $R^{2}$ & 0.703 & 0.000 \\
Kleibergen and Paap (2006) test $(p$-value) & & 0.901 \\
Centered $R^{2}$ & & 0.204 \\
Hausman's specification test $(p$-value) & & \\
\hline
\end{tabular}

Notes: The dependent variable is the natural logarithm of the change in education stock (19702010). Standardized coefficients are reported with heteroskedasticity - robust standard errors in parentheses. Asterisks denote significance levels as follows: ${ }^{\star \star \star} p<0.01,{ }^{\star \star} p<0.05$, ${ }^{*} p<0.1$. Initial values are measured as of 1970 . The null hypothesis of the Hausman test is that the difference in coefficients of the OLS and TSLS is not systematic. Although the reported standard errors are heteroskedasticity consistent, the implementation of the Hausman test does not allow correcting for heteroskedasticity.

spending on education as an instrument for its average value over the period 1970-2010. Here, the idea is that the initial value of public spending on education influences its average value but is not directly correlated with education attainment growth. We use the Hansen $J$-test of overidentifying restrictions to test the validity of this excluded instrument. We present the OLS estimates because the Hausman specification test suggests that there is no difference between the coefficients of the OLS and TSLS estimators. In such a case, the OLS estimator is more efficient than the TSLS estimator given that the latter uses less information than the former. Once again, initial education stock, public spending, and undernourishment remain significant and with the right signs. All other independent variables remain statistically insignificant. 


\section{Education Spending and Performance: Some Additional Observations}

The regression results suggest that we should look for differences among regions in initial stocks of education and rates of public spending on education in order to understand why some regions have done better than others in education performance since these are the two most important variables in terms of economic and statistical significance. We could add undernourishment to this list since it is also consistently significant in our results though of much less explanatory importance.

Table 7: Cross-regional differences in significant determinants of education attainment.

\begin{tabular}{lrrr}
\hline Regions & $\begin{array}{r}\text { Initial education } \\
\text { stock in } \mathbf{1 9 7 0}\end{array}$ & $\begin{array}{r}\text { Public spending } \\
\text { per capita per year }\end{array}$ & $\begin{array}{r}\text { Undernourishment } \\
\text { (\%) }\end{array}$ \\
\hline Middle East and North Africa & 2.1 & 252.3 & 7.0 \\
East Asia and Pacific & 3.9 & 74.8 & 15.6 \\
Europe and Central Asia & 6.0 & 197.4 & 7.8 \\
Latin America and Caribbean & 4.4 & 219.6 & 11.8 \\
South Asia & 2.4 & 8.4 & 21.9 \\
Sub-Saharan Africa & 1.9 & 37.3 & 27.5 \\
\hline
\end{tabular}

Table 7 compares regions in terms of these three independent variables. This shows that MENA had the second lowest value for initial education, the highest value for public spending on education and the best (lowest) value for undernourishment. Thus, it is clear that MENA's comparative edge comes from its low initial education stock and its high rate of public spending on education. The only pairwise comparison where initial education stock does not give MENA an edge is for the case of Sub-Saharan Africa where the latter had a lower stock (of 1.9 years) to begin with. In this case, however, the huge spending gap between MENA and Sub-Saharan Africa (\$252 per capita per year versus \$37) accounts for the performance edge. The same applies to a pairwise comparison with South Asia: since the two regions started off with approximately the same stocks in 1970, it was the far higher rate of public spending in MENA that accounted for the difference in the change in education stocks over time. MENA's low rate of undernourishment adds to its edge in all pairwise comparisons but only slightly since this variable has much lower explanatory value and economic significance.

Between initial education stock and public spending, only the latter is of policy relevance. So it is worth investigating other aspects of MENA's public 
spending as well, such as its efficiency. We have data on public spending for the period 1980-2010. From this, we can calculate the amount of education achieved per dollar spent as well as the amount of spending needed to obtain an additional year of education stock. These two calculations are shown for all developing country regions in Table 8.

Table 8: Cost effectiveness of public spending on education (1980-2010).

\begin{tabular}{lrr}
\hline Region & $\begin{array}{r}\text { Increase in education stock } \\
\text { achieved by spending } \mathbf{\$ 1 0 0} \text { per } \\
\text { capita per year }\end{array}$ & $\begin{array}{r}\text { Per capita spending per year } \\
\text { needed to add } \mathbf{1} \text { year to } \\
\text { education stock }\end{array}$ \\
\hline Middle East and North Africa & 1.54 & 64.69 \\
East Asia and Pacific & 3.47 & 28.76 \\
Europe and Central Asia & 1.31 & 75.92 \\
Latin America and Caribbean & 1.32 & 75.72 \\
South Asia & 34.52 & 2.89 \\
Sub-Saharan Africa & 7.23 & 13.81 \\
\hline
\end{tabular}

The first column of Table 8 shows that MENA achieved 1.54 years of additional education stock per $\$ 100$ in public spending per capita per year. This is somewhat better than that achieved by Latin America and Europe/Central Asia but much worse than that achieved by South Asia and Sub-Saharan Africa. A similar ranking may be seen when considering the amount of per capita education spending that was needed to add 1 year to the cumulative education stock. MENA spent close to $\$ 65$ per capita per year (in 2005 purchasing power parity (PPP) terms) to achieve each additional year of schooling, faring somewhat better in this regard than Latin America and Europe/Central Asia but much worse than South Asia, Sub-Saharan Africa, and East Asia.

The seemingly super-efficient numbers for South Asia need some comment. South Asia spent only $\$ 2.89$ to obtain an additional year of education stock. This reflects the much lower education input costs (for example, on teacher salaries and school buildings) of the much poorer countries that comprise that region. It should also be noted that, despite its relative efficiency, South Asia did not increase its education stock as much as MENA because it spent far less ( $\$ 8.4$ per capita compared to $\$ 252.3$ as shown in Table 7).

A second aspect of the link between education spending and performance is that of quality. ${ }^{7}$ It is generally acknowledged that the quality of education in

7 The shortcomings of education in MENA have been insightfully addressed in a number of Arab Human Development Reports put out by the United Nations (see, in particular, UNDP 2002). 
MENA leaves a lot to be desired. The limited, though growing, body of comparative data on education quality shows most MENA countries clustered in the bottom half of the global distribution. For example, 13 MENA countries participated in one or more segments of the 2007 and 2011 rounds of TIMSS (Trends in International Mathematics and Science Study) but none scored above the global average. While such a result may be expected of less developed countries with few resources to spend on education, it is surprising for MENA which is a middle-income region and has been spending considerable resources on education.

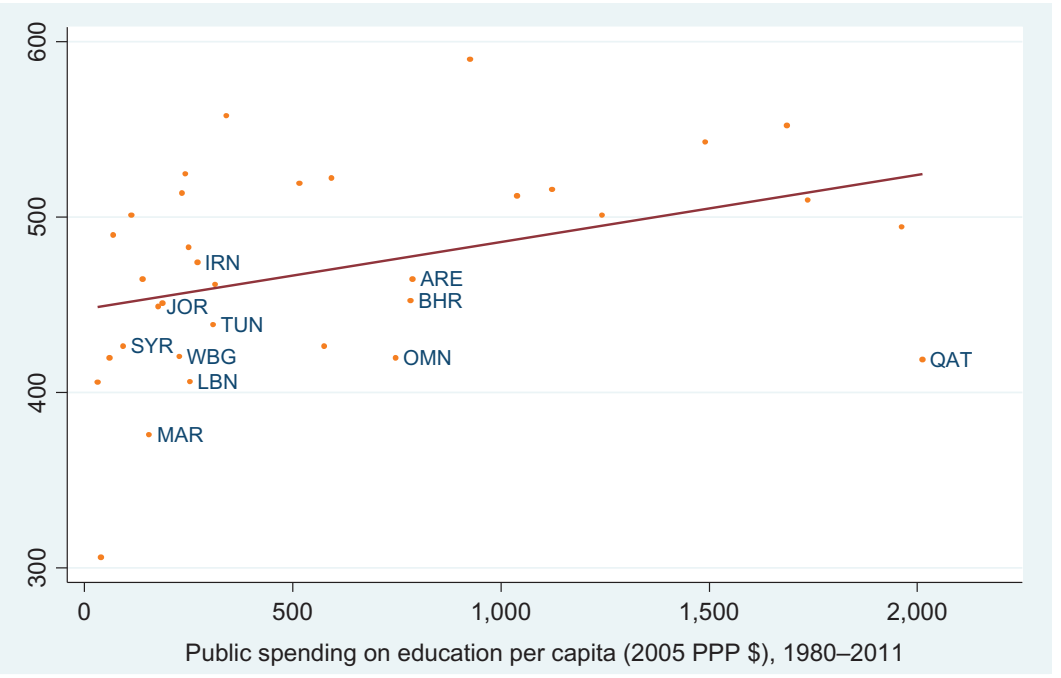

Figure 2: Public spending on education and TIMSS score for Mathematics. Source: Trends in International Mathematics and Science Study, 2011 accessible at http://www.iea.nl/data.html

Figure 2 shows a scatter plot of country-level TIMSS scores (for mathematics at the eighth-grade level in 2011) and public spending on education (averaged over 1980-2010). MENA countries are labeled and all but Iran can all be seen to fall below the bivariate regression line. Similar results are obtained for other measures of education quality, such as the TIMSS score for science. This suggests that MENA countries have underperformed in terms of education quality in relation to their levels of public spending.

Recent research also suggests that student characteristics (such as parent's education and exposure to books at home) tend to be more important than school characteristics (such as teacher qualifications and class sizes) in 
explaining test scores in MENA countries (see Badr et al. 2012). All this leads to the conclusion that while the challenge of hiring teachers, building schools and getting children into classrooms has been successfully met in MENA that of converting all this schooling into productive learning remains to be met in the future.

\section{Annex 1: Regional country composition}

\section{East Asia and Pacific (EAP)}

American Samoa, Brunei Darussalam, Cambodia, China, Fiji, French Polynesia, Guam, Hong Kong SAR, China, Indonesia, Kiribati, the Democratic People's Republic of Korea, the Lao People's Democratic Republic, Macao SAR, China, Malaysia, the Federated States of Micronesia, Mongolia, Myanmar, New Caledonia, Northern Mariana Islands, Palau, Papua New Guinea, Philippines, Singapore, Solomon Islands, Thailand, Timor-Leste, Tonga, Tuvalu, Vanuatu, Vietnam.

\section{Europe and Central Asia (ECA)}

Albania, Andorra, Armenia, Azerbaijan, Belarus, Bosnia and Herzegovina, Bulgaria, Channel Islands, Croatia, Cyprus, Faeroe Islands, Georgia, Greenland, Hungary, Isle of Man, Kazakhstan, Kosovo, Kyrgyz Republic, Latvia, Liechtenstein, Lithuania, Macedonia, FYR, Moldova, Monaco, Montenegro, Romania, Russian Federation, San Marino, Serbia, Tajikistan, Turkey, Turkmenistan, Ukraine, Uzbekistan.

\section{Latin America and the Caribbean (LAC)}

Antigua and Barbuda, Argentina, Aruba, The Bahamas, Barbados, Belize, Bolivia, Brazil, Cayman Islands, Chile, Colombia, Costa Rica, Cuba, Curacao, Dominica, the Dominican Republic, Ecuador, El Salvador, Grenada, Guatemala, Guyana, Haiti, Honduras, Jamaica, Mexico, Nicaragua, Panama, Paraguay, Peru, Puerto Rico, Sint Maarten (Dutch part), St. Kitts and Nevis, St. Lucia, St. Martin (French part), St. Vincent and the Grenadines, Suriname, Trinidad and Tobago, Turks and Caicos Islands, Uruguay, República Bolivariana de Venezuela, Virgin Islands (USA). 


\section{Middle East and North Africa (MENA)}

Algeria, Bahrain, the Arab Republic of Egypt, the Islamic Republic of Iran, Iraq, Jordan, Kuwait, Lebanon, Libya, Morocco, Oman, Qatar, Saudi Arabia, the Syrian Arab Republic, Tunisia, United Arab Emirates, West Bank and Gaza, the Republic of Yemen.

\section{South Asia (SA)}

Afghanistan, Bangladesh, Bhutan, India, Maldives, Nepal, Pakistan, Sri Lanka.

\section{Sub-Saharan Africa (SSA)}

Angola, Benin, Botswana, Burkina Faso, Burundi, Cameroon, Cape Verde, Central African Republic, Chad, Comoros, the Democratic Republic of Congo, the Republic of Congo, Côte d'Ivoire, Equatorial Guinea, Eritrea, Ethiopia, Gabon, The Gambia, Ghana, Guinea, Guinea-Bissau, Kenya, Lesotho, Liberia, Madagascar, Malawi, Mali, Mauritania, Mauritius, Mozambique, Namibia, Niger, Nigeria, Rwanda, São Tomé and Principe, Senegal, Seychelles, Sierra Leone, Somalia, South Africa, Sudan, Swaziland, Tanzania, Togo, Uganda, Zambia, Zimbabwe.

\section{Annex 2: Variable definitions and sources}

\begin{tabular}{lll}
\hline Variable & Definition & Source \\
\hline $\begin{array}{l}\text { Change in } \\
\text { education stock }\end{array}$ & $\begin{array}{l}\text { Change in average years of } \\
\text { schooling per person over the age of } \\
\text { 15, between 1970 and 2010 }\end{array}$ & $\begin{array}{l}\text { Barro and Lee (2013) http://www. } \\
\text { barrolee.com/ }\end{array}$ \\
Initial education & $\begin{array}{l}\text { Average years of schooling per } \\
\text { person over the age of 15 as of 1970 }\end{array}$ & $\begin{array}{l}\text { Barro and Lee (2013) http://www. } \\
\text { barrolee.com/ }\end{array}$ \\
Public spending & $\begin{array}{l}\text { Public spending on education per } \\
\text { capita per year measured in 2005 }\end{array}$ & $\begin{array}{l}\text { Statistics of Public Expenditure and } \\
\text { Economic Development; International }\end{array}$ \\
& PPP dollars & $\begin{array}{l}\text { Food Policy Research Institute http:// } \\
\text { www.ifpri.org/tools/speed }\end{array}$ \\
& $\begin{array}{l}\text { Urban population as percent of total } \\
\text { population }\end{array}$ & $\begin{array}{l}\text { World Development Indicators, } \\
\text { World Bank; http://data.worldbank. } \\
\text { org/data-catalog/world- } \\
\text { Urban }\end{array}$ \\
& & $\begin{array}{l}\text { development-indicators } \\
\end{array}$
\end{tabular}


(continued)

\begin{tabular}{|c|c|c|}
\hline Variable & Definition & Source \\
\hline Undernourishment & $\begin{array}{l}\text { Proportion of population whose food } \\
\text { intake is insufficient to meet } \\
\text { minimum dietary energy } \\
\text { requirements continuously }\end{array}$ & $\begin{array}{l}\text { World Development Indicators, } \\
\text { World Bank; http://data.worldbank. } \\
\text { org/data-catalog/world- } \\
\text { development-indicators }\end{array}$ \\
\hline Child employment & $\begin{array}{l}\text { Children in employment as } \\
\text { percentage of all children aged 7-14 }\end{array}$ & $\begin{array}{l}\text { World Development Indicators, } \\
\text { World Bank; http://data.worldbank. } \\
\text { org/data-catalog/world- } \\
\text { development-indicators }\end{array}$ \\
\hline $\begin{array}{l}\text { Control of } \\
\text { Corruption }\end{array}$ & $\begin{array}{l}\text { Index reflecting control over } \\
\text { corruption and ranging from }-2.5 \\
\text { (weak) to } 2.5 \text { (strong) }\end{array}$ & $\begin{array}{l}\text { Worldwide Governance Indicators, } \\
\text { World Bank; http://info.worldbank. } \\
\text { org/governance/wgi/index. } \\
\text { aspx\#home }\end{array}$ \\
\hline Growth & $\begin{array}{l}\text { Annual percentage change in GDP } \\
\text { per capita measured in } 2005 \text { dollars }\end{array}$ & $\begin{array}{l}\text { World Development Indicators, } \\
\text { World Bank; http://data.worldbank. } \\
\text { org/data-catalog/world- } \\
\text { development-indicators }\end{array}$ \\
\hline GDP per capita & $\begin{array}{l}\text { GDP per capita (constant } 2005 \\
\text { dollars) }\end{array}$ & $\begin{array}{l}\text { World Development Indicators, } \\
\text { World Bank; http://data.worldbank. } \\
\text { org/data-catalog/world- } \\
\text { development-indicators }\end{array}$ \\
\hline Ethnic Tensions & $\begin{array}{l}\text { Assessment of the degree of tension } \\
\text { within a country attributable to racial, } \\
\text { nationality, or language divisions. } \\
\text { Scored from } 0 \text { to } 6 \text { with higher values } \\
\text { indicating lower tension. }\end{array}$ & $\begin{array}{l}\text { International Country Risk Guide } \\
\text { (ICRG); https://www.prsgroup.com/ } \\
\text { about-us/our-two-methodologies/ } \\
\text { icrg }\end{array}$ \\
\hline $\begin{array}{l}\text { TIMSS Math score } \\
\text { for eighth grade } \\
\text { students }\end{array}$ & $\begin{array}{l}\text { Mean performance on the } \\
\text { mathematics scale for eighth grade } \\
\text { students from the TIMSS round of } \\
\text { 2011; the global average is set at } 500\end{array}$ & $\begin{array}{l}\text { International Association for the } \\
\text { Evaluation of Educational } \\
\text { Achievement (IEA); } \\
\text { http://www.iea.nl/data.html }\end{array}$ \\
\hline
\end{tabular}

\section{References}

Badr, M., O. Morrissey, and S. Appleton. 2012. "Determinants of Educational Attainment in MENA." Research Paper 2012:03,Center for Research in Economic Development and International Trade,University of Nottingham.

Baldacci, E., B. Clements, S. Gupta, and Q. Cui. 2008. "Social Spending, Human Capital, and Growth in Developing Countries.” World Development 36 (8):1317-41.

Baldacci, E., M. Guin-Sui, and L. de Mello. 2003. "More on the Effectiveness of Public Spending on Health Care and Education: A Covariance Structure Model." Journal of International Development 15(6):709-25. 
Barro, R. 1991. "Economic Growth in a Cross-Section of Countries." Quarterly Journal of Economics 106(2):407-43.

Barro, R., and J. Lee. 2013. "A New Data Set of Educational Attainment in the World, 1950-2010." Journal of Development Economics 104:184-98.

Clemens, M. A., C. J. Kenny, and T. J. Moss. 2007. "The Trouble with the MDGs: Confronting Expectations of Aid and Development Success." World Development 35(5):735-51.

Corden, W. M. 1984. "Booming Sector and Dutch Disease Economics: Survey and Consolidation." Oxford Economic Papers 36(3):359-80.

Glewwe, P., and M. Kremer. 2006. "Schools, Teachers and Education Outcomes in Developing Countries." In Handbook of the Economics of Education, Volume 2, edited by E. Hanushek and F. Welch, Elsevier B.V. Amsterdam: Netherlands.

Goldin, C., and L. Katz. 1997. Why the United States Led in Education: Lessons from Secondary School Expansion, 1910 to 1940. Working Paper 6144, Cambridge, MA: National Bureau of Economic Research.

Gupta, S., M. Verhoeven, and E. Tiongson. 2002. "The Effectiveness of Government Spending on Education and Health Care in Developing and Transition Economies." European Journal of Political Economy 18:717-37.

Hanushek, E. 1995. “Interpreting Recent Research on Schooling in Developing Countries.” The World Bank Research Observer 10(2):227-46.

Iqbal, F. 2006. Sustaining Gains in Poverty Reduction and Human Development in the Middle East and North Africa. World Bank.

Kleibergen, F., and R. Paap. 2006. "Generalized Reduced Rank Tests Using the Singular Value Decomposition.” Journal of Econometrics 133(1):97-126.

Rajkumar, A., and V. Swaroop. 2008. "Public Spending and Outcomes: Does Governance Matter?” Journal of Development Economics 86:96-111.

Rugh, W. 2002. "Arab Education: Tradition, Growth and Reform." Middle East Journal 56(3):396-414.

Solow, R. 1956. "A Contribution to the Theory of Economic Growth." Quarterly Journal of Economics LXX:65-94.

United Nations Development Program (UNDP). 2002. Arab Human Development Report. New York: United Nations. 